\title{
A recepção teológica da Exortação Apostólica pós-sinodal Verbum Domimi
}

\author{
Orientador: Prof. Antônio Luiz Catelan Ferreira \\ Pesquisador: Eduardo de Souza Pimentel \\ Fonte: $\mathrm{CNPq}$
}

\section{Introdução}

Foi realizado um estudo acerca da recepção teológica da exortação Verbum Domini, trabalhando o conceito de recepção na Teologia, buscando o contexto da Constituição Dogmática Dei Verbum, a sua recepção e comentários posteriores a sua publicação, o desenvolvimento da compreensão da Sagrada Escritura como Palavra, comunicação e revelação de Deus, a preparação da XII Assembleia Geral Ordinária do Sínodo dos Bispos, os pontos abordados e o resultado que se dá na Exortação Apostólica Verbum Domini. A partir do estudo deste documento magisterial e de comentários, foi buscado compreender a sua recepção teológica na Igreja, como também o lugar da Sagrada Escritura.

\section{Objetivos}

Compreender, de modo teórico e prático, o papel e o significado da Sagrada Escritura e do Magistério na produção teológica; conhecer a discussão teológica referente à recepção eclesial da atuação do Magistério; inserir-se na discussão teológica contemporânea a partir do estudo da recepção de um texto magisterial de alta importância para a vida e a missão eclesial, a teologia, o ecumenismo e o diálogo inter-religioso. 